\title{
Discussion on Positive Effects for Students' Moral Development from Integrating Mentors and Doctoral Students into One Party Branch
}

\author{
Li Wu${ }^{1}$, Zhenjia Sun'a \\ ${ }^{1}$ School of Foreign Languages, Beihang University 100083 \\ ${ }^{2}$ School of Aeronautic Science and Engineering, Beihang University, 100083
}

\begin{abstract}
The word "mentor" comes from the Odyssey by the Greek poet Homer. Odyssey entrusted his friend Mentor to care for and educate his son, Telemachus.The word "mentor" later refers to a trustworthy advisor, counsellor and friend.A mentoring relationship has been defined as a "nurturing process in which a more skilled or experienced person, serving as a role model, teaches, sponsors, encourages, counsels and befriends a less skilled or less experienced person" (Anderson \& Shannon, 1988). This paper mainly focuses on how to successfully mentor the doctoral students through the integration of mentors and doctoral students into one party branch.
\end{abstract}

Keywords: Moral development; Mentor-doctoral student; Integration; Integrated social units.

\section{Introduction}

To be an excellent student, both academic achievement and moral development count. Schooling exerts influences upon students' social and moral development not only in classroom, but also in the "hidden curriculum" which are, by and large, implicit and unobserved. Teachers may pay enough attention to the academic content to be conveyed in their lessons. However, teachers need to pay more attention to the students' moral development, so that they could become mentors. Mentors are the advisors who share career experience and share their knowledge. They are also the supporters who give students emotional and moral encouragement as well as specific feedbacks on their performance. To integrate mentors and doctoral students into one Party branch proves to be one of the most effective ways in which to benefit students' moral development through creating an interactive community.By taking the "Department of Literature" from the school of Foreign Languages, Beihang University, where mentors workand the "Longitudinal Student Party Branch for Doctoral Students" which doctoral students of School of Foreign Languages belong to as the pilot objects, the methods and the positive effects of establishing a Party Branch of Teacher-Student Integration are discussed.

\section{Discussion}

\subsection{The pedagogy of makarenko}

School is a "bridge" between the affective morality of the family and the more "rigorous" morality of society. Anton Makarenko, a Soviet Ukrainian educator,noted, "social pedagogues must try to turn groups of young people into collectives, integrated social units that hold joint goals and loyalty among members. A collective makes up a link between the individual and society." He described how the elder colonists made a decisive impact on the younger ones. He argued that the way these grownups lead their own private lives is more important than their use of educational methods.

To integrate mentors and doctoral students into one Party brach creates an atmosphere for a group of young good students with great achievement in studies to get positive effects from their mentors And the mentors are definitely positive models in some leisure activities designed to integrate themselves and the doctoral students into one Party branch, which can be regarded as a group work, Mentors can be positive models, making a decisive impact on the younger ones. In fact, as Makarenko argued, the way these grown-ups live their own private lives is more important than their use of educational methods. From the point of that view, mentors' participating in the same Party branch with their students may be more helpful than their teaching in class.

\subsection{The methods of integrating}

In order to facilitate management, most colleges and universities generally divide Party branches into the faculty Party branch and the student Party branch. The faculty Party branch mainly carries out activities in the forms of theoretical study, document transmission, lectures and reports, which, however, lacks vitality and

\footnotetext{
a Corresponding author: szj@buaa.edu.cn
} 
innovation. Owing to lots of teaching and research activities, most of faculty's enthusiasm wanes in the longterm single theoretical study process, which directly results in a weak leadership of the organizational life of the faculty Party branch, a less prominent vanguard role of the faculty Party members as well as a lack of enthusiasm of organizational life for more and more teachers. As for the student Party branch, due to the limited number of students and inadequate familiarity with their work, it cannot shoulder the responsibility of the Party branches' work very well, which leads to unsound Party branch organization, less Party activities, a lack of understanding of theoretical study and organizational life, and the unsatisfactory learning effect. The insufficient training to student Party members and active applicants for Party membership and the difficulty to meet the real needs of students' development result in a less prominent vanguard role of the student Party members as well as the deficient cohesiveness of Party branches.

Doctoral student Party members are outstanding among doctoral student groups in colleges and universities, who have rich theoretical knowledge, active thoughts, mature world outlook and values. The Party branch which doctoral student Party members rely on is the basic organization for education and management of Party members, the basic unit and important starting point of Party construction for doctoral students in colleges and universities and the important position for carrying out ideological and political education for doctoral students. It plays an important role in training high-quality, topnotch and innovative talents. However, due to the complexity of the current social trend of thoughts, some doctoral student Party members have weak vanguard and exemplary consciousness, insufficient Party spirit and unwillingness to take the initiative to work collectively, which have affected the overall role of the Party branches. As for teachers in colleges and universities, they should insist that educators receive education first, strive to become a communicator of advanced ideology and culture and a staunch supporter of the Party's ruling and better take the responsibility as instructors and guides for students' healthy growth. Colleges and universities should strengthen the construction of teachers' professional ethics, and teachers should adhere to the combination of teaching and educating students. It is necessary to give full play to the role of the primary responsibility of the advisors in ideological and political education for graduate students. And teachers shall at the same time be urged to care for their students, be strict with and diligent in academic pursuits, stay indifferent to fame and gain, value self-respect and self-discipline, affect students with personal charisma and scholastic excellence and provide guidance to ensure students grow in a healthy way. Obviously, it's necessary and meaningful to integrate them into one Party branch.

\subsection{The positive effects of integrating}

By taking "Party Branch of Department of Literature" and "Longitudinal Student Party Branch for Doctoral
Students" where doctoral advisors of School of Foreign Languages belong as the pilot objects, the methods of establishing a Party Branch of Teacher-Student Integration and Party branch construction norms are discussed. Based on the adherence to grade or department setting, to establish the graduate student Party branches by relying on research teams led by mentors seems to be an effective link between students' life and their social practice. What will emerge, I believe, is a fairly clear picture of the characteristics of schools that should do a good job of promoting prosocial and ethical development in their students. Taking "Party Branch of Department of Literature" and "Longitudinal Student Party Branch for Doctoral Students" where doctoral advisors of School of Foreign Languages belong as the pilot objects, the methods and strategies of establishing a Party Branch of Teacher-Student Integration and Party branch construction norms are researched and discussed. These methods and strategies are aimed at strengthening students' ideological construction and training outstanding Party members engaged in scientific research and technology who are both socialist-minded and professionally competent by starting from Party branch construction to build a communication platform between advisors and doctoral students beyond classrooms and academic seminars. Besides, they are also designed to intensify the ideological and political education responsibility of advisors from School of Foreign Languages to further establish a harmonious relationship between advisors and students, and enhance the vitality of Party branches as well as creatively carry out Party branch activities to pass on moral, ideological and academic values to advisors and students. The importance of positive interpersonal relationships to moral socialization is hardly surprising. As the doctoral students, the party branch provides them with an ideal environmentto feel accepted and valued by their mentors, who show care for them, and adopt their beliefs and values. The party branch characterized by caring and supportive relationships between teachers and students and among students should be optimal for promoting prosocial and moral development, in that such an environment is one which both provides abundant models of behavior consistent with prosocial and moral attitudes and values, and motivates the student to adopt and internalize these attitudes, values, and behaviors. Being in a same party branch with the doctoral students' mentors means they can not only be advised, but also develop an extended relationship in which both the mentor and student focus on the student's academic, career, and personal growth. Mentors can promote their students' character development. They can structure student interactions in ways that facilitate a sense of shared purpose. And they can also directly influence students by teaching important social skills, and helping students to apply those skills in relevant situations. In the moral domain, mentors should be moral advocates, using their "moral authority" as older, wiser, and more expert members of society to help their students attain moral maturity by raising issues, ensuring that all views are heard in discussing problems, and focusing the discourse on fundamental issues of caring and justice. Many 
mentoring relationships extend well beyond graduate school and continue throughout the student's career.

\section{Conclusion}

The doctoral students seek mentors for research, creative activities, teaching, and career development. And mentors may not only provide students with knowledge and skills in graduate school, but may also offer support and guidance throughout the future career and even the whole life. The party branch provides a new way for the relationship of mentors and students except for the classroom. Just as it requires a comprehensive assessment of outcomes, the mentor-student interaction requires a comprehensive assessment of implementation,.

Given the current upsurge in character and moral education, we have an opportunity to assess the effectiveness of interpreting the mentors and students into one branch in our school. Doing a good job of assessing is critical to determining "what works" in character education. The difficulty is to gather data which can do much more to our understanding of character education. And still, there are some issues we need to solve, such as how to coordinate the differences in majors and academic researches of doctoral students in Longitudinal Party branches, and how to innovate the forms of Party branch activities to enhance the interest and enthusiasm of teachers and students to participate in Party branch activities. However, the consequences are problematic. At best, relegating school influences on social and moral development to the form of the group work with their mentors does not provide students with clear messages about how we should live our lives, and denies them an important source of guidance from adult members of society as they strive to understand themselves and the world around them; at worst, it helps them to have a "world view" and depiction of the relations between individuals in society that runs counter to the aims of promoting students' moral and character development.

\section{References}

1. Anton Makarenko Halvorsen, T. Key pedagogic thinkers: Anton Makarenko. Journal of Pedagogic Development, 2014, 4 (2), pp.58-71.

2. Ali PA, Panther W. Professional development and the role of mentorship. Nurs Stand, 2008, Jun 25-Jul 1, 22 (42): 35-9.

3. Anderson E., \& Shannon A.. Toward a conceptualization of mentoring. Journal of Teacher Education, 1988, 39 (1), 38-42. 